\title{
On Difference between Administrative Penalty and Administrative Coercive Measures-Analysis on Prosecution of East Star Against CAAC South Central Management Bureau
}

\author{
Lingjie Xu \\ Civil Aviation Flight University of China, Guanghan, 618307, China
}

Keywords: Administrative penalty. Administrative coercive measures. Difference. Civil aviation. Suggestions

\begin{abstract}
The focus of prosecution of East Star Aviation against CAAC South Central Management Bureau lies in whether the legal nature of the decision of CAAC South Central Management Bureau on "ordering East Star Aviation to stop its flight" is administrative penalty or administrative coercive measures. By comparing the differences between the administrative penalty and administrative coercive measures in purpose, function, implementation premise, action independence, finality, justiciability and the risk of infringing the right of administrative counterpart and in combination with the case condition, it is analyzed that the decision on flight stop is an immediate and emergency administrative coercive measures taken by CAAC South Central Management Bureau against the major hidden danger of East Star Aviation which might endanger the public security, and it is further pointed out that safety is the life of civil aviation, the civil aviation authority should strictly require the safety, ensure zero maintenance and supervise the safety continuously, and it is suggested to regulate the establishment and implementation of civil aviation administrative coercive measures according to Administrative Compulsory Law of China.
\end{abstract}

\section{Case introduction}

East Star Aviation Co., Ltd. ("East Star Aviation") with East Star as the big shareholder was registered on December 22, 2005. On March 14, 2009, Wuhan Municipal Government General Office issued Letter of Wuhan Municipal People's Government on Stopping Flight of East Star Aviation Company to Civil Aviation Administration of China South Central Management Bureau (CAAC South Central Management Bureau), stating that "there was artificial obstacle in the reorganization between East Star Aviation and CAAC, "East Star Aviation owns too many debts" and "actual controller of East Star Aviation goes abroad arbitrarily without permission", and required CAAC South Central Bureau to stop the flight of East Star Aviation. On the same day, CAAC South Central Bureau made the decision on stop all flights of East Star Aviation" in the form of express telegraph. In August 2009, East Star Aviation was declared to be bankrupted. East Star Group thought it was the improper administrative law enforcing of CAAC South Central Bureau that caused the bankruptcy liquidation of East Star Aviation, and the overall breakdown of East Star Group, and prosecuted CAA C South Central Bureau and requested the court to judge administrative penalty of flight stop invalid.

During the trial, Guangzhou Baiyun District court held that civil aviation industry is a special industry, shouldering the social responsibility for the life and property security of the passengers, and in case of hidden danger that might endanger the public safety interest, the industrial management department should take immediate and emergency administrative coercive measures. In the continuous monitoring to East Star Aviation, the CAAC South Central Bureau found that the company had many serious problems endangering the flight safety, and these problems still were not improved upon the order of CAAC South Central Bureau for rectification. In addition, Wuhan Municipal Government where East Star Airline is located also reflected that East Star Airline had major hidden danger in the process of reorganization, and issued a letter to CAAC South Central Management Bureau. The court held that the administrative coercive measures taken by CAAC South Central Management Bureau according to the investigated facts were proper, although there were 
defects such as no informing of rights, such defects would not influence the affirmation of the fact of the case. Therefore, the request of East Star Aviation to cancel the administrative act of CAAC South Central Management Bureau of flight stop for illegal treatment procedures had not enough reasons and was rejected according to the law. [1] Afterwards, East Star Group instituted an appeal. On April 22, 2012, Guangzhou Municipal Intermediate People's Court rejected the appeal and maintained the final judgment of the original trial.

The dispute focus of this case was whether the decision made by CAAC South Central Management Bureau on stopping flight of East Star was administrative penalty or administrative coercive measures. For a long time before the unveiling of Administrative Compulsory Law in June 2012, the competent administrative departments of various industries of China were of independent legislation and law enforcement, making the administrative coercive measures in the situation of "being excessive, disordered and weak", especially there was no definition between the immediate coercive measures such as "ordered to stop" and administrative penalty of "ordered to stop production and business", causing mixing in practice. [2] (P34), in the present case, the dispute on the nature of "stopping flight" is the reflection of such issue in the field of civil aviation. Therefore, to analyze the nature of decision on stopping flight, it is necessary to analyze the difference between administrative penalty and administrative coercive measures.

\section{Difference between administrative penalty and administrative coercive measures}

Administrative penalty means the administrative act of person, property, dispute and in other forms of legal sanction imposed by the administrative subject to the administrative counterpart for violation of legal provisions not constituting crime in accordance with the law in order to achieve the purpose of punishing the law breaker, urging no violation again, effective implementing the administrative management, maintaining the public interest and social order and protecting the legal rights and interest of the citizens, legal persons or other organizations. [3](P220)

Administrative coercion means the coercive measures taken by the administrative subject for the property, body and freedom of the administrative counterpart in order to achieve the administrative purpose. [3] (P234). Article II of Administrative Compulsory Law specifies that "the administrative coercion referred to in this law includes the administrative coercive measures and administrative enforcement. Administrative coercive measures means the behavior of temporarily limit the personal freedom of citizens or temporary control of the properties of citizens, legal persons or other organizations implemented by the administrative authority in the process of administrative management in accordance with the law in order to stop the illegal behavior, prevent evidence being damaged, avoid hazard and control the danger expansion et."

Administrative penalty and administrative coercive measures are two scopes of administrative law that are easy to be mixed.

First, both belong to the specific administrative action, and from the consequence of action, adverse legal consequence occurs to the administrative counterpart, with the meaning of "punishment";

Second, both have some external similarities, for example, "ordering to stop production and business" as administrative penalty and "ordering to stop business for rectification" as the administrative coercive measures are extremely similar, and need to be clearly distinguished from the purpose and procedure of administrative act;

Fourth, both have the similar purpose, both are for the purpose of guarantee the smooth proceeding of administrative act, but the administrative penalty is often the sanction to the counterpart violating the law, and to urge the administrative counterpart to comply with the legal regulations; while the administrative coercive measures is to force the counterpart to comply with the legal regulations by compulsory means. The former has a stronger sense of purpose, while the latter has a stronger sense of means.

As the specific administrative behaviors, although the two are similar, there are more differences: 


\section{Different purposes and functions}

Sanction is the natural characteristic of administrative penalty, the purpose and function of administrative penalty are to implement the legal regulations by carrying out sanction to the administrative counterpart violating the law; while the nature purpose and function of administrative conceive measures are to guarantee the implementation of administrative orders and decisions by the compulsory measures, eliminate the obstacle in administrative activity and maintain the normal administrative management order, and in theory, it should not be punitive. The purpose of administrative coercive measures is to prevent, stop or control the occurring of society-damaging behavior, with obvious property of prevention and stop.

\section{Different premises}

The administrative penalty is based on the premise that the counterpart violates the law, and is a penalty to the lawbreaker; while the administrative coercive measures are not based on the premise that the counterpart violates the law, for example retention and examination, those subject to retition and examination are only suspected of illegality and crime, and even cooperate with the investigation in accordance with the law, but are not the definite lawbreakers.

Different risks to the infringement of the counterpart's rights, so the corresponding power supervision and right relief requirements are also different.

The derive of the administrative penalty of the counterpart's rights must be based on the fact that the counterpart violates the law; however, when the lawful administrative coercive measures infringe the counterpart's rights, the counterpart may not violate the law necessarily. For example, the public security authority's retention to the counterpart suspected of crime is the infringement to the counterpart's personal freedom, whether the counterpart has the criminal behaviors indeed, such retention behavior is lawful as long as there is no abuse of power. Thus, it is unavoidable for the administrative coercive measures to infringe the counterpart's rights. Therefore, under the requirements of legal governance, it is required to strictly limit the administrative coercive measures, prevent the abuse of administrative power and avoid the improper judgment of the administrative subject.

\section{Different independences}

The administrative penalty is in an independent administrative behavior mode; but the administrative coercion is often combined with other administrative behaviors, and sometimes it is even closely combined and it is difficult to whether it belongs to administrative coercion. For example, compulsory expropriation can be both regarded as administrative expropriation and administrative coercion. [4] (P9).

\section{Different ends of behavior}

Once made, the administrative penalty cannot be changed and canceled without legal procedures, while the administrative coercive measures are to stop the illegal behavior, prevent evidence being destructed, avoid hazard occurring and control the hazard expansion by compulsory means, or to promote the counterpart to perform the obligations. Once the above emergency situation appears or the obligator has performed the obligations, the administrative coercion shall be stopped.

In addition, administrative penalty is an independent, single and complete administrative behavior, while the administrative coercive measures are the only temporary disposal in legal situation, once the situation disappears, the disposal shall be terminated, or another specific administrative behavior will proceed. For example, the tools suspected of illegal behaviors are retained, and administrative penalty is made after investigation. Therefore, the administrative coercive measures are generally the prelude and preparation for the final treatment decision of the administrative authority, with obvious temporality and intermediary.

\section{Different justiciabilities of behaviors}

The administrative penalty, as a specific administrative action, is justiciable according to the provisions of Clause 11.1 of Administrative Procedural Law of China. Although the administrative coercive measures belong to specific behavior within the scope of administrative cases accepted by the court, not any objection to the administrative coercive measures may be subject to administrative proceedings to the court. Whether the administrative coercive measures are justiciable depends on the 
relation between the administrative coercive measures and the rights and interests of the administrative counterpart.

\section{(7) Different severities}

Administrative coercive measures are the compulsory action take to individual and organization by using the power of the state apparatus, therefore, it is required to be quite prudent when taking the administrative coercive measures; whether the administrative authority is entitled to take the administrative coercive measures must be authorized by the law, and the measures shall be implemented according to the legal procedures. For this, there are detailed provisions in Articles 4, 9, 10 and 11 of Administrative Compulsory Law; and there is no strict administrative coercion for the administrative penalty.

\section{Nature of decision on "stopping flight"}

It can be seen from the development of the course in the case that East Star Group prosecutes against CAAC South Central Management Bureau that the decision on stopping flight is temporary, emergent non-punitive, it is just because there are many hidden dangers in the operation of East Star operation that Hubei Safety Supervision Bureau, CAAC South Central Bureau and the CAAC and even Wuhan Municipal People's government have become aware of it and took measures for rectification and regulation in the operation of East Star Aviation, but in consideration of the particularity of civil aviation transportation and the higher requirements of civil aviation for safety, therefore, the emergency measures, the administrative coercive measures to stop the flight were finally taken in order to prevent or stop the danger and the temporality of adverse subsequences.

\section{Suggestions to regulate the administrative coercive measures for civil aviation}

Safety is the life of civil aviation. The continuous supervision is the important and man work of the civil aviation management unit. For the hidden danger found in the inspection of civil aviation transportation enterprises, the competent civil aviation units often will take the measures of sealing up, detention and suspension of use, as well as flight stop so as to prevent the occurring of accident. For example, on September 1, 2010, CAAC Southwest Management Bureau issued Notice on Suspending Operation of China Express Airlines and decides to suspend the operation of China Express Airlines for 5-15 days. [5]

However, the administrative coercive measures have the characteristics of emergency, and in procedure, it is often impossible to have full investigation, evidence taking and decision making etc. like the administrative penalty. Therefore, how to prevent the administrative coercive measures taken in emergency from infringing the legal rights of the administrative counterpart both reflects the particularity of administrative coercive measures, and is also an important content to perfect the administrative compulsory system. In combination with the management affairs of the administrative management of civil aviation, the author suggests as follows:

First, perfecting the legislation on administrative coercive measures for civil aviation

Sort out the provisions in civil aviation laws, regulations and rules involved in the administrative coercive measures according to the provisions of implemented and effective Administrative Compulsory Law. Reserve those conforming to the legislation authorization and types specified in Administrative Compulsory Law and abolish those exceeding the legal authorization. It is suggested to establish Measures for Implementation of Administrative Coercion for Civil Aviation, regulate the type, setting and implementation procedures of administrative coercive measures, especially during legislation, it is required to describe the "emergency:" according to the actual condition of civil aviation activity, so as to avid the explanation by the administrative management authority in case of lack of fairness and reduction of image of administrative management and effect of administrative action.

Second, improving the law enforcement for administrative coercive measures for civil aviation 
The emergency of administrative coercive measures makes the implementation procedures for the coercive measures not prudent enough, and the administrative coercive measures are easier to infringe the interest of the administrative counterpart, therefore, it is required to pay attention to and perfect the law enforcement procedures, it is suggested to modify Administrative Law Enforcement Volume for Civil Aviation Supervisor and perfect the law enforcement procedures according to ht provisions of Administrative Penalty Law.

Third, strengthen the legal training of law enforcement personnel and improve their legal consciousness. Only when the law enforcement personnel improve their legal consciousness can they correctly understand the spirit and purpose of law and achieve the win-win objective of safety development and right and interest protection in the process of law enforcement supervision.

\section{References}

[1]Zhang Hongyan, Shen Minghui, "Prosecution of East Star Against CAAC South Central Management Bureau" Failed in First Instance, recorded on http://news.carnoc.com/list/207/207706.html, visited on May 15, 2012

[2] Hu Jianshen, Jin Fengwei et al., Empirical Analysis on Current Situation of Administrative Coercive Measures involved in Existing Laws, Regulations and Rules of China [J]. Beijing: Legal Forum, 2000 (6)

[3] Jiang Ming'an Administrative Law and Administrative Procedural Law [M], Beijing: Peking University Press, Higher Education Process, 2003

[4] Mo Yuchuan, Operation Rules and Case of Administrative Coercion [M], Beijing: Law Press, 2011

[5] Wing Touching Ground, China Express Airlines to be Suspended for Flight for to 15 days, recorded in people's network http://finance.people.com.cn/GB/12599534.html, visited on May 15, 2012 